\title{
SCREENING OF BACTERIAL POPULATIONS IN CROP ROTATIONS WITH DIFFERENT PROPORTION OF CEREALS
}

\author{
KATARÍNA ONDREIČKOVÁ*, MÁRIA BABULICOVÁ, DANIEL MIHÁLIK, \\ MARCELA GUBIŠOVÁ, JOZEF GUBIŠ
}

National Agricultural and Food Centre

ONDREIČKOVÁ, K. - BABULICOVÁ, M. - MIHÁLIK, D. - GUBIŠOVÁ, M. - GUBIŠ, J.: Screening of bacterial populations in crop rotations with different proportion of cereals. Agriculture (Polnohospodárstvo), vol. 60, 2014, no. 1, pp. 31-38.

Terminal restriction fragment length polymorphism was used to determine the bacterial community diversity in crop rotations with different proportion of cereals $(40 \%$, $60 \%$ and $80 \%)$ and various fertilisation treatments (F1 mineral fertiliser amendment + the application of organic fertiliser Veget ${ }^{\circledR}$ and $F 2$ - mineral fertilisation) sampled on two dates (July and October 2012). No statistically significant differences in the number of terminal restriction fragments were detected by Fisher's least significant difference between two types of fertilisation or among samples with different proportion of cereals. In contrast, statistically significant differences were detec- ted between samples collected in July and October, when in October there was a $43.5 \%$ reduction in the number of bacterial species in comparison with July. Principal component analysis as well as cluster analysis showed that a higher similarity in composition of bacterial communities was present among all soil samples collected in July and two samples collected in October. Other samples collected in October were separated from each other. The results of this study demonstrated that bacteria abundance and community composition were not affected by the proportion of cereals and fertiliser used.

Key words: crop rotation, bacterial community, diversity, fertilisation, T-RFLP, 16S rRNA gene

Soil microorganisms play a key role in nutrient cycling as they support the decomposition of organic matter, and thus increase the availability of nutrients to plants (Yu et al. 2013). On the other hand, the structure of the microbial community is mainly affected by plant species, agricultural management and abiotic factors (Hu et al. 1999; Lupwayi et al. 1998; Peacock et al. 2001). Traditional methods for identification and characterisation of microorganisms are based on the cultivation in liquid or solid media (Torsvik et al. 1990 ), but only $0.001 \times 0.1 \%$ of the total bacterial population from natural habitats can be cultivated using standard culture media (Ward et al. 1992). For this reason, cultivation method is very limiting, and thus molecular methods began to be used to identify microorganisms that require the isolation of DNA (Nordgard et al. 2005). One of the most used methods is terminal restriction fragment length polymorphism (T-RFLP) (Liu et al. 1997), which is a method of comparative community analysis. Metagenomic DNA isolated from environmental samples is used as a template in PCR to amplify the marker gene (mainly 16S rRNA gene for prokaryotes and 18S rRNA gene for eukaryotes). Forward primer is fluorescently labelled on the 5 ' end. PCR products are digested with one or more restriction endonucleases, fragments are separated in capillary electrophoresis, and only terminal restriction fragments (T-RFs) containing fluorescently labelled primer are detected. The result of T-RFLP analysis 
is the profile that consists of T-RFs. T-RFs are then identified by comparing their sizes with DNA standards. Each T-RF represents one operational taxonomic unit that is defined as a group of $16 \mathrm{~S}$ rDNA sequences having the same size of T-RFs (Moeseneder et al. 1999). Each peak represents a specific species or group of microorganisms.

At present, many farmers increase the proportion of cereals in crop rotations. Therefore, the research was realised in crop rotations with $40 \%, 60 \%$ and $80 \%$ proportion of cereals. The aim of this study was to screen and investigate changes in soil bacterial diversity as a result of the impact of different proportion of cereals and various fertilisation treatments using PCR amplification of 16S rRNA gene followed by the T-RFLP method.

\section{MATERIAL AND METHODS}

\section{Characterisation of field experiment}

The presented results are a part of a long-term field experiment established in 1974 in the maize and barley producing area at the Experimental Station Borovce belonging to the Research Institute of Plant Production in Piešt'any, Slovak Republic. The experimental fields at Borovce are located at an elevation of $167 \mathrm{~m}$ above sea level. The region is characterised by continental climate with an average annual rainfall of $593 \mathrm{~mm}(358 \mathrm{~mm}$ during the vegetation season) and long-term average annual temperature of $9.2^{\circ} \mathrm{C}(15.5$ during the vegetation season). The soil characteristics of field plots are as follows: Haplic Chernozem. The depth of plow layer was $0.24-0.28 \mathrm{~m}$. The depth of mollic horizon was $0.40-0.55 \mathrm{~m}$; it was differentiated in the upper (eluvial) and under (illuvial) layer. At a depth of $0.50-0.85 \mathrm{~m}$, the mollic horizon proceeded into calciferous loess. Conventional ploughing to depth $0.22-0.25 \mathrm{~m}$, sowing, fertilisation and plant treatments were performed according to recommendations for the given area. The pesticide treatments were realised according to the actual occurrence of diseases, pests and weeds. Crop rotations are introduced in Table 1. Doses phosphorus and potassium were calculated according to the balance methodology (P, K) (Bizík et al. 1998), and dose of nitrogen was calculated by the methodology of Ložek (1998). The amounts of nutrients are declared in Table 2. Two types of fertilisation were used: F1 - mineral fertiliser amendment + the application of organic fertiliser (Veget $\left.{ }^{\circledR}\right)$ and F2 - mineral fertilisation. Veget ${ }^{\circledR}$ was applied at a dose of 5 tons per hectare per year. The composition of organic fertiliser Veget ${ }^{\circledR}[C \check{O V}$, a. s., Biotika, a. s., Slovenská L’upča, Slovakia] is as follows: dry matter content $\min .85 \%$ (includes combustible matter content $75 \%$; total $\mathrm{N}$ content 2.5-3.0\%; total $\mathrm{P}_{2} \mathrm{O}_{5}$ content $0.5-2.0 \%$, and $\mathrm{K}_{2} \mathrm{O}$ content $1.5 \%$ ), ratio $\mathrm{C}: \mathrm{N} 13: 1$ and $\mathrm{pH}$ (in water) 8.5. Veget ${ }^{\circledR}$ is produced from waste materials after industrial antibiotic production.

\section{T-RFLP analysis}

Soil samples were collected from a depth of 10 $\mathrm{cm}$ on two dates, $2^{\text {nd }}$ July and $24^{\text {th }}$ October 2012, and exact daily rainfall and temperature measured at monthly intervals prior to the collection of soil samples as illustrated in Figure 1. In July, all plots were planted with winter wheat, but in October the

$\mathrm{T}$ a

The crop rotations with $40 \%, 60 \%$ and $80 \%$ proportion of the cereals

\begin{tabular}{|l|l|l|}
\hline \multicolumn{2}{|c|}{ Crop rotation } \\
\hline \multicolumn{1}{|c|}{$40 \%$ cereal proportion } & \multicolumn{1}{|c|}{$60 \%$ cereal proportion } & \multicolumn{1}{c|}{$80 \%$ cereal proportion } \\
\hline 1. pea & 1. pea & 1. winter wheat \\
2. winter wheat & 2. winter wheat & 2. spring barley \\
3. silage maize & 3. winter barley & 3. pea \\
4. spring barley & 4. silage maize & 4. winter wheat \\
5. grain maize & 5. spring barley & 5. winter barley \\
\hline
\end{tabular}


representation of crops was different: plot with $40 \%$ proportion of cereals was without crop; plots with $60 \%$ and $80 \%$ proportion of cereals were sown with winter barley. Soil samples were collected from three different sites in each plot and stored at $4^{\circ} \mathrm{C}$. Each soil sample was thoroughly homogenised and metagenomic DNA was extracted by the PowerSoil DNA Isolation Kit (MoBio Laboratories Inc.) in triplicate from each plot. Concentration and purity of isolated DNA were pre-measured by Nanodrop 1000 Spectrophotometer (Thermo Scientific), and samples were diluted to the same final concentration $(25 \mathrm{ng} / \mu 1)$. DNA amplification was carried out in 50 $\mu 1$ reaction mixture containing FailSafe ${ }^{\mathrm{TM}}$ PCR PreMix Selection Kit (Epicentre Biotechnologies), 0.10 $\mu \mathrm{M}$ of both primers and $1 \mu \mathrm{l}(25 \mathrm{ng})$ of DNA extracted from soil. Bacterial universal primers for the 16S rRNA gene 8F (AGAGTTTGATCCTGGCTCAG, FAM labelled) (Edwards et al. 1989) and 926R (CCGTCAATTCCTTTRAGTTT) (Muyzer et al. $1995)$ were used. PCR was performed using the programme: $3 \mathrm{~min}$ at $95^{\circ} \mathrm{C}, 35$ cycles of $30 \mathrm{~s}$ at $94^{\circ} \mathrm{C}$, $30 \mathrm{~s}$ at $47^{\circ} \mathrm{C}, 1 \mathrm{~min}$ at $72^{\circ} \mathrm{C}$ and final polymerisation $10 \mathrm{~min}$ at $72^{\circ} \mathrm{C}$ in GeneAmp PCR System 9700 (Applied Biosystems). Three separate PCR mixtures from each plot were pooled, and PCR products were purified by the PCR Purification \& Agarose Gel Extraction Combo Kit (Ecoli s.r.o.) according to the manufacturer's protocol. After purification, PCR products were digested with $C f o$ I restriction enzyme (Roche). Digestion mixture (total volume $20 \mu \mathrm{l}$ ) containing $10 \mathrm{U}$ of restriction enzyme, $2 \mu 1$ of 10 $\times$ buffers and $10 \mu \mathrm{l}$ of purified PCR reaction mixture was incubated for $3 \mathrm{~h}$ at $37^{\circ} \mathrm{C}$. Samples were purified after cleavage using a purification kit mentioned above. T-RFs were separated by electrophoresis in ABI Prism 3100 Avant apparatus (Applied Biosystems) with LIZ 1200 internal standard. Electrophoretograms were analysed by GeneMapper 3.5 (Applied Biosystems). Only fragments between 70 bp and 915 bp were used for evaluation.

\section{Statistical analysis}

The results obtained were statistically evaluated by Fisher's least significant difference (LSD) procedure at the $95.0 \%$ confidence level. Bacterial communities in different samples were compared by the presence/absence of specific T-RFs. T-RF peaks were classified as present (1) or absent (0) in each sample, and the binary system was used for principal component analysis (PCA) using the Statgraphics XV.II statistical program. Binary system was also used to create a dendrogram using UPGMA clustering and Jaccard's similarity coefficient by the DARwin software (http://darwin.cirad.fr/darwin; Perrier and Jacquemoud-Collet 2006).

\section{RESULTS}

The number of T-RFs detected after digestion with $C f o$ I ranged from 25 to 61 for samples collected in July and from 6 to 27 for samples collected in October. The total of 92 different T-RFs from July

$\mathrm{T}$ a

The fertilisation in crop rotations with $40 \%, 60 \%$ and $80 \%$ proportion of the cereals in 2012

\begin{tabular}{|c|c|c|c|c|c|c|c|c|c|c|c|c|}
\hline \multirow{3}{*}{ Nutrients } & \multicolumn{12}{|c|}{ Dosage of nutrients $[\mathrm{kg} / \mathrm{ha}]$} \\
\hline & \multicolumn{4}{|c|}{$40 \%$} & \multicolumn{4}{|c|}{$60 \%$} & \multicolumn{4}{|c|}{$80 \%$} \\
\hline & \multicolumn{2}{|c|}{$\mathrm{F} 1$} & \multicolumn{2}{|c|}{$\mathrm{F} 2$} & \multicolumn{2}{|c|}{$\mathrm{F} 1$} & \multicolumn{2}{|c|}{$\mathrm{F} 2$} & \multicolumn{2}{|c|}{$\mathrm{F} 1$} & \multicolumn{2}{|c|}{$\mathrm{F} 2$} \\
\hline $\mathrm{N}$ & & 105 & & 105 & & 105 & & 105 & & 105 & & 105 \\
\hline $\mathrm{P}$ & $\mathrm{H}$ & 0 & $\mathrm{H}$ & 0 & $\mathrm{H}$ & 0 & $\mathrm{H}$ & 0 & G & 30 & G & 30 \\
\hline \multirow[t]{2}{*}{$\mathrm{K}$} & $\mathrm{H}$ & 0 & G & 100 & $\mathrm{H}$ & 0 & $\mathrm{H}$ & 0 & G & 100 & G & 100 \\
\hline & \multicolumn{2}{|c|}{ Veget $₫$} & & & \multicolumn{2}{|c|}{ Veget $\AA$} & & & \multicolumn{2}{|c|}{ Veget $\AA$} & & \\
\hline
\end{tabular}

Supply of nutrients in the soil: L - low; G - good; H - high; VH - very high

F1 - mineral fertiliser amendment + the application of organic fertiliser (Veget $\left.{ }^{\circledR}\right)$, F2 - mineral fertilisation 
and 52 different T-RFs from October were obtained using the enzyme $C f o \mathrm{I}$; this means a $43.5 \%$ reduction of bacterial species in October (LSD, $P<0.05$ ). Simultaneously, the number of detected T-RFs among individual soil samples was very different, but statistically significant differences were not detected (LSD, $P>0.05$ ) (Figure 2). T-RFs detected in all variants (ubiquitous T-RFs) were present only

June-July 2012

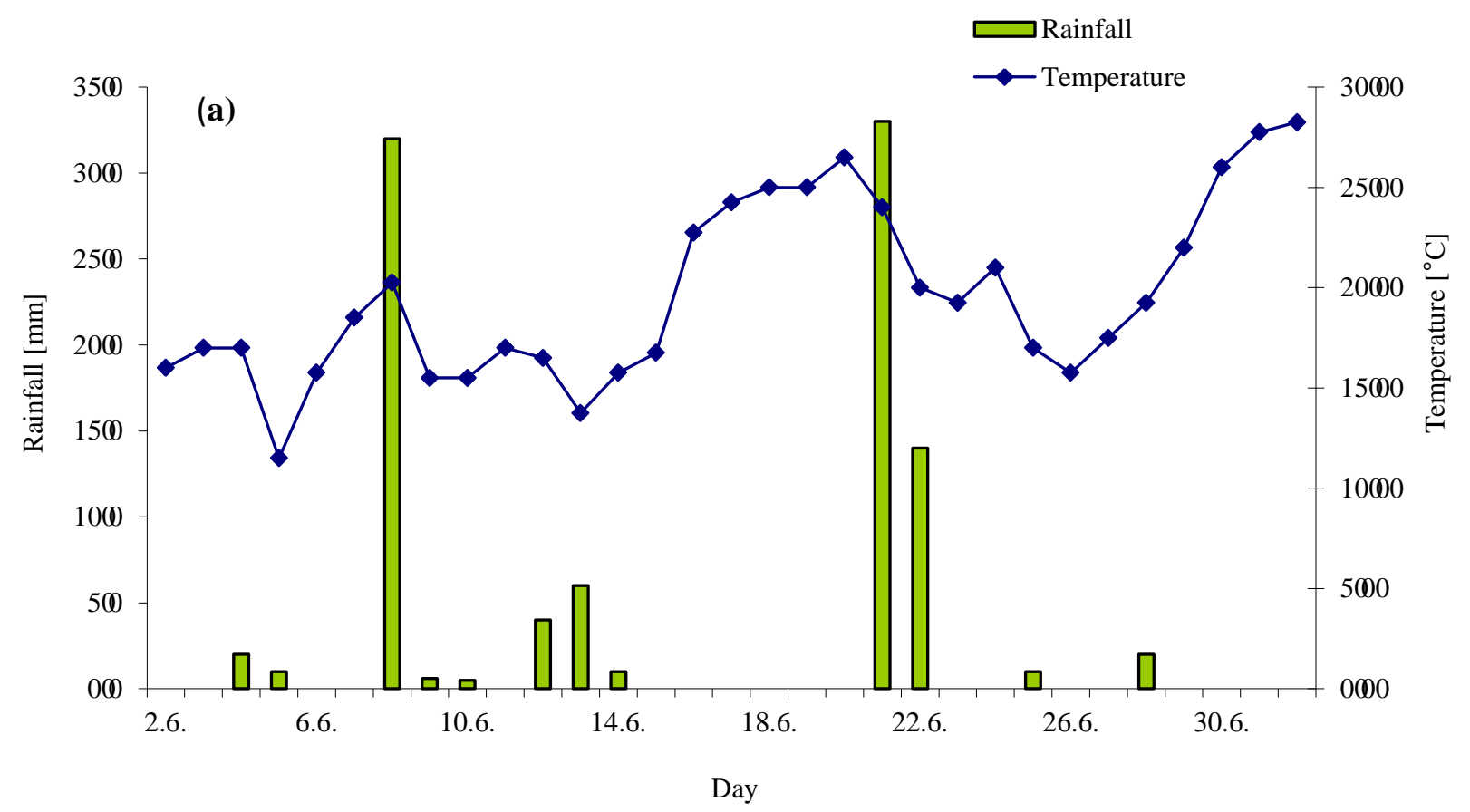

September-October 2012

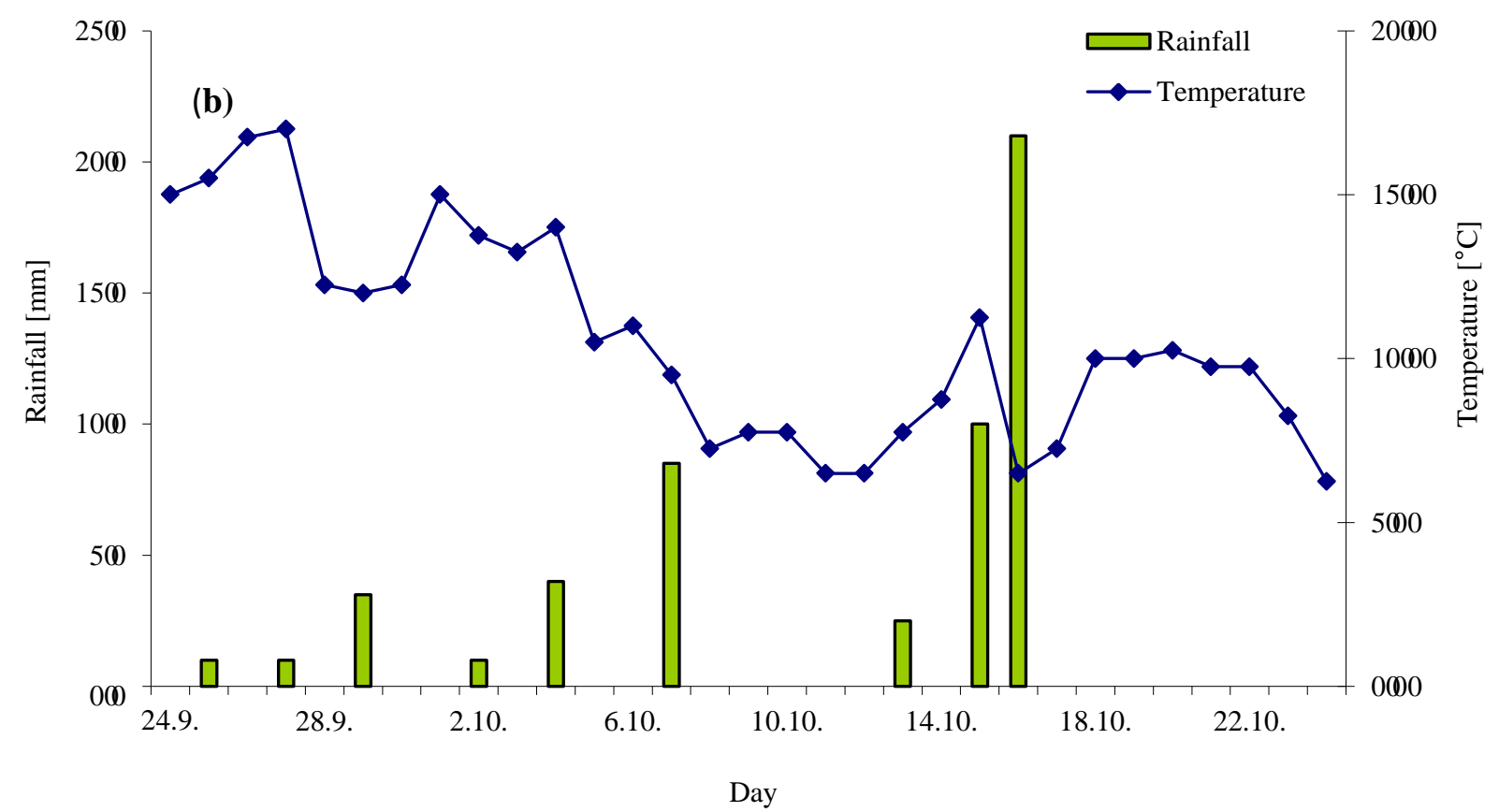

Figure 1. Daily rainfall and temperature measured at the research station in Borovce; measured values represent

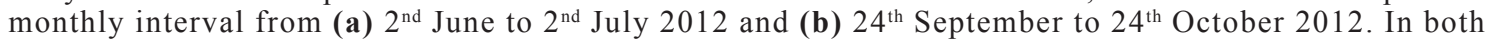
graphs, the curves represent temperature and the columns represent rainfall. 
in soil samples collected in July. The intensities of the fluorescent signals of these T-RFs were different for each sample (Figure 3), but in each sample the highest fluorescence corresponded with fragments of $76 \mathrm{bp}, 505 \mathrm{bp}$ and $199 \mathrm{bp}$, respectively. All ubiquitous T-RFs could reflect the most commonly occurring bacteria in summer time or bacteria specific for soil in experimental location. In October, these T-RFs were detected in 0-4 soil samples; sample F2 $40 \%$ did not have any ubiquitous T-RFs from July. On the other hand, in samples F1 80\% and F2 80\%, eight T-RFs identical to July ubiquitous T-RFs were detected. Simultaneously, the July ubiquitous T-RF $211 \mathrm{bp}$ was not present in any soil sample collected in October. The sizes of experimentally obtained ubiquitous T-RFs from July were compared with in silico T-RFs of known bacteria using the program MiCA 3 (http://mica.ibest.uidaho.edu/, Shyu et al. 2007) in order to obtain an approximate view of the specific groups of bacteria contained in each soil sample. Seven out of ten ubiquitous T-RFs most likely correspond to the Proteobacteria group (specifically 77 bp and $505 \mathrm{bp}$ - Alphaproteobacteria, $199 \mathrm{bp}$ and 203 bp - Betaproteobacteria, 87 bp - Gammaproteobacteria, 89 bp - Deltaproteobacteria, 211 bp Proteobacteria). Two ubiquitous T-RFs correspond to the Firmicutes group (76 bp and $660 \mathrm{bp}$ ) and one to the Actinobacteria group (197 bp). PCA analysis shows that the similarity in composition of bacterial communities between soil samples was higher in
July than in October (Figure 4). Samples F1 80\% and F2 80\% collected in October reveal high mutual conformity in bacterial composition, and in the PCA graph they are placed separately from the other samples. This suggests that there was no influence of various fertilising on significant changes in bac-

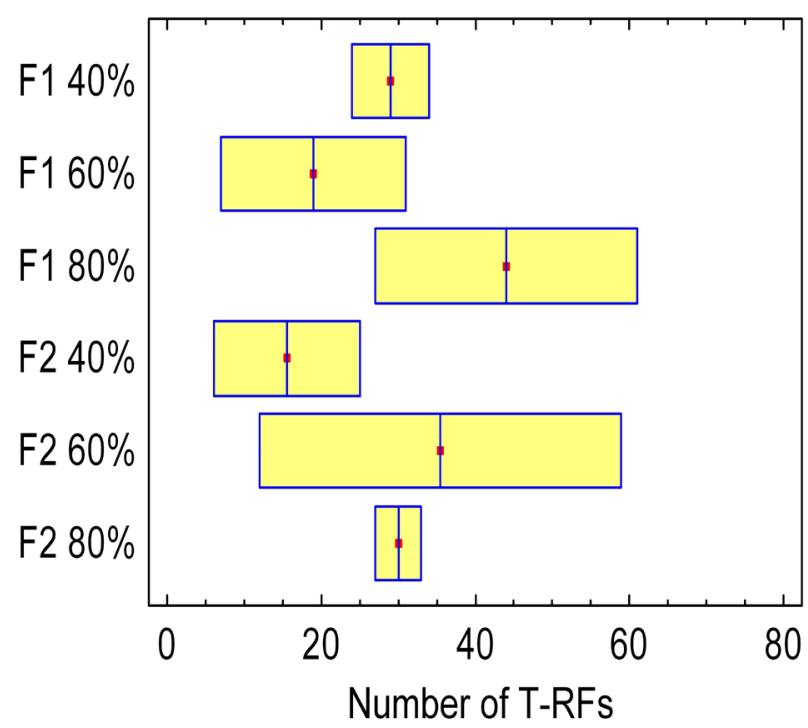

Figure 2. Box-and-Whisker plot from soil samples with different proportion of cereals $(40 \%, 60 \%$ and $80 \%$ ) and various fertilisation treatments (F1 - mineral fertiliser amendment + the application of organic fertiliser Veget ${ }^{\circledR}$ and F2 - mineral fertilisation) collected in 2012 . Plot was constructed from the number of detected terminal restriction fragments in individual soil samples collected on two dates. No statistically significant differences were detected among samples (LSD, $P>0.05$ ).

\section{Fragment size (bp)}

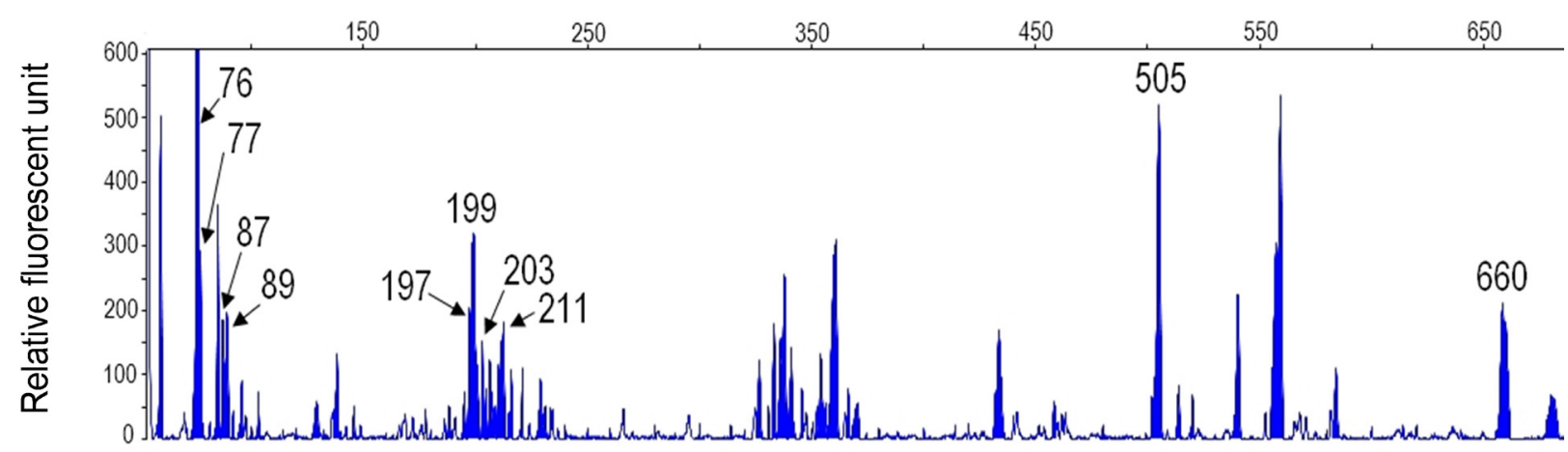

Figure 3. $16 \mathrm{~S}$ rDNA-based T-RFLP fingerprint pattern obtained with $C f o$ I restriction enzyme of soil sample with $80 \%$ proportion of cereals and with mineral fertiliser amendment + the application of organic fertiliser Veget ${ }^{\circledR}$ collected in July 2012. Terminal restriction fragments that were detected in July in all soil samples (ubiquitous terminal restriction fragments) are marked with the respective sizes in bp. 


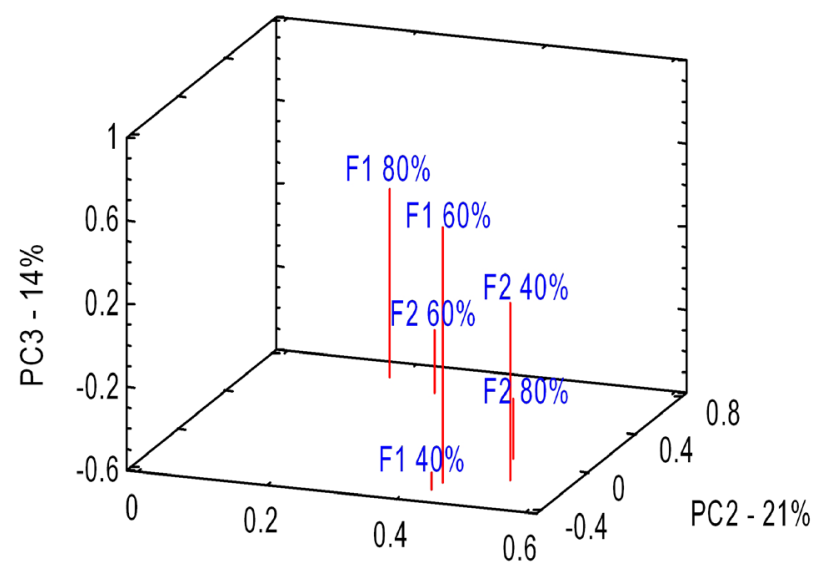

PC1 - 39\%

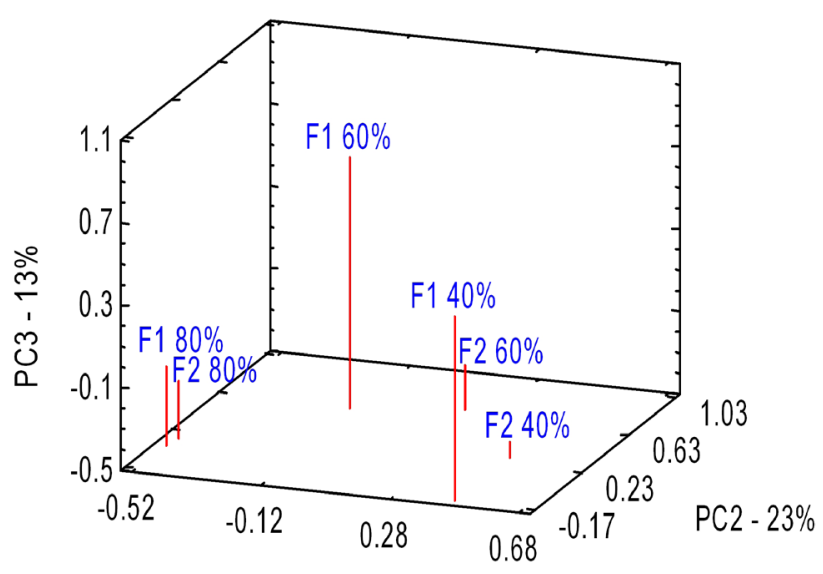

PC1 - 38\%

Figure 4. Principal component analysis (PCA) of terminal restriction fragment length polymorphism profiles of bacterial communities from soil samples with different proportion of cereals $(40 \%, 60 \%$ and $80 \%)$ and various fertilisation treatments (F1 - mineral fertiliser amendment + the application of organic fertiliser Veget ${ }^{\circledR}$ and F2 - mineral fertilisation) created by using binary data. Samples collected in July are in the left PCA graph and samples collected in October are in the right PCA graph and the relative similarity of samples is characterised by proximity to each other. Both PCA graphs explained $74 \%$ of the variability in the data.

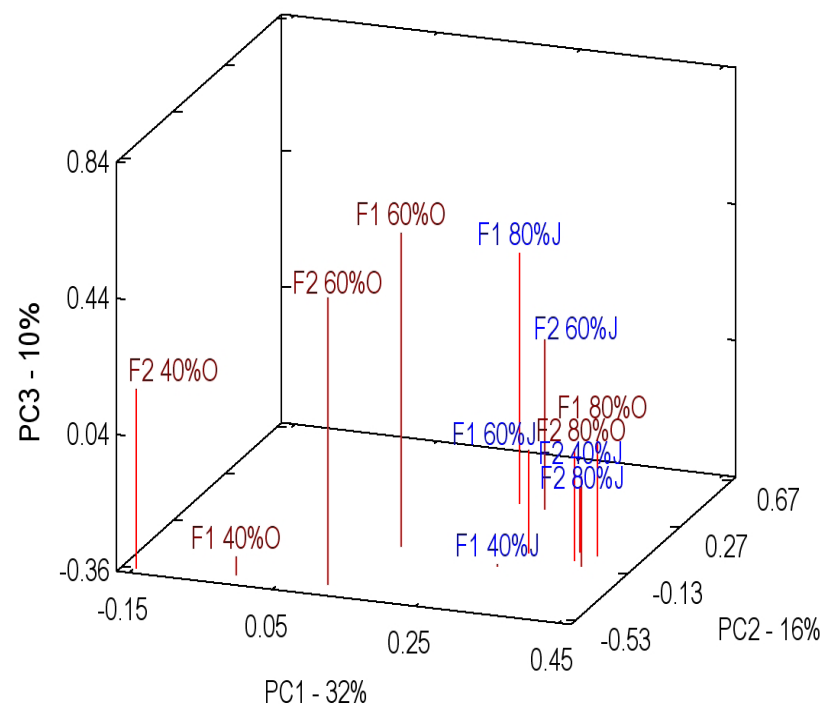

Figure 5. Principal component analysis constructed from soil samples with different proportion of cereals $(40 \%, 60 \%$ and $80 \%)$ and various fertilisation treatments (F1 mineral fertiliser amendment + the application of organic fertiliser Veget ${ }^{\circledR}$ and F2 - mineral fertilisation) collected on two dates in 2012 (letter after the name of the sample in PCA graph indicates the collection period: July - J, October - O). The first, second and third principal components explained $32 \%, 16 \%$ and $10 \%$ (respectively) of the variability in the data with a total of $58 \%$ of the variability. The relative similarity of samples is characterised by proximity to each other.

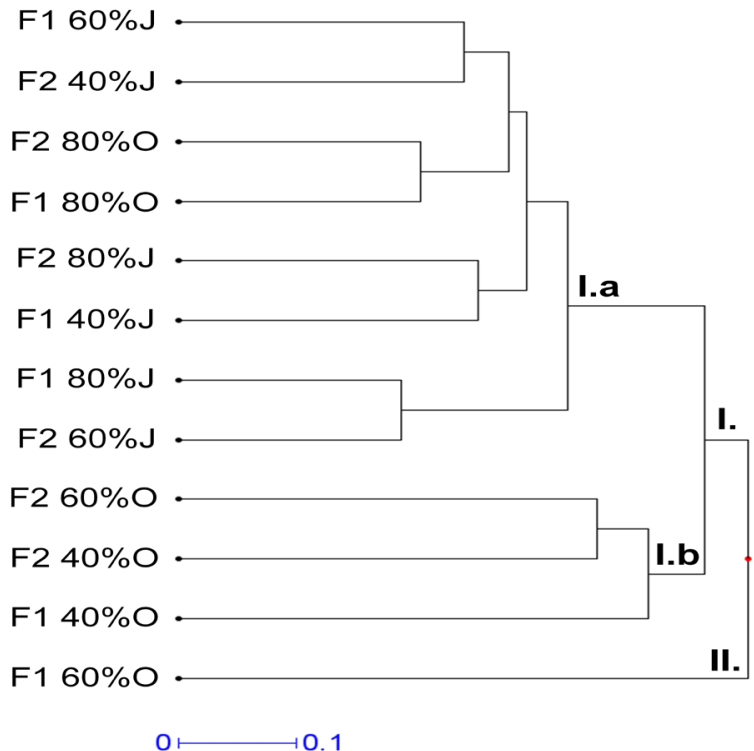

Figure 6. Relationship between bacterial communities in soil samples with different proportion of cereals $(40 \%, 60 \%$ and $80 \%)$ and various fertilisation treatments (F1 - mineral fertiliser amendment + the application of organic fertiliser Veget ${ }^{\circledR}$ and F2 - mineral fertilisation) collected on two dates in 2012 (letter after the name of the sample in dendrogram graph indicates the collection period: July - J, October-O). Dendrogram was constructed using unweighted pair group method with arithmetic mean generated from Jaccard distance matrix of terminal restriction fragment profiles obtained with $C f o$ I restriction enzyme. The bar in the bottom of the dendrogram represents the Jaccard distance measure. 
terial communities in this case. The October sample F1 $60 \%$ is located between the two more compact set of samples consisting of F1 80\% + F2 80\% and F1 40\% + F2 40\% + F2 60\% (Figure 4 right). PCA analysis constructed from all samples collected in July and October confirmed the similarity between all the July samples (Figure 5). Also, the October samples F1 80\% and F2 80\% were assigned to these July samples, indicating their differences from the other October samples. The remaining four samples from October were separated from each other. The cluster analysis based on the calculated Jaccard's coefficient (Figure 6) presents two main clusters (I and II); while cluster I is divided into two smaller clusters (Ia and Ib). All the July samples with samples F1 80\% and F2 80\% from October form the single cluster Ia. In cluster Ib, there are three samples, F2 40\%, F2 60\% and F1 40\%, collected in October. The October sample F1 60\% creates a completely separate cluster II, which suggests the difference in bacterial composition in comparison with the other samples.

\section{DISCUSSION}

Soil microbial biomass is closely related with soil fertility (Yao et al. 2000) because it defines the quality and productive capacity of soils (Fernandes et al. 1997). It is also regarded as one of the most sensitive indicators for evaluating the sustainability of a management system (Gregorich et al. 1997). The application of T-RFLP method in combination with PCA and cluster analysis provides a useful tool for detection of differences in soil bacteria communities and their abundance. The results of this study demonstrated that the bacteria abundance and community composition were not affected by the proportion of cereals and fertiliser used, mainly samples collected in July. Statistical differences detected between collection periods could be caused by different temperature and rainfall, too. Particularly, the rising temperature and higher rainfall recorded before first soil sampling in July could provide better conditions for the growth of various bacteria. On the contrary, in October, falling temperature with lower rainfall could lead to decreased soil bacterial diver- sity as a consequence of deteriorative conditions. Yu et al. (2013) observed small changes in the bacterial community structures depending on long-term land use and fertilisation by DGGE method, and they also did not detect any significant correlations between bacterial diversity and soil properties. They suggest that soil bacterial community is not strongly driven by the type of fertilisers and soil management strategies. The result from this study was also similar to the observations of Sarathchandra et al. (2001) who detected that nitrogen and phosphate fertilisers had no significant effect on soil microbial populations using the cultivation method. Poulsen et al. (2013) also found no major changes in the community composition due to different fertiliser treatments using pyrosequencing and they demonstrated a high robustness of the soil microbiota.

\section{CONCLUSIONS}

This study has demonstrated no significant changes in soil bacterial community composition between the two types of fertilisation. Also, composition of soil bacterial community was not affected by different proportion of cereals in crop rotation, even in $80 \%$ proportion of cereals. Significant changes were observed only in the sampling period, i.e. between July and October, while in October there was a decrease of bacterial species.

Acknowledgement. This work was supported by Operational Programme Research and Development: Development and installation of lysimeters equipment for the rational farming on land in sustainable crop production (ITMS 26220220106) from European Regional Development Fund.

\section{REFERENCES}

BIZÍK, J. - FECENKO, J. - KOTVAS, F. - LOŽEK, O. 1998. Methodology of crop fertilization and nutrition. Bratislava : AT Publishing, 113 pp. ISBN 80-967812$1-9$

EDWARDS, U. - ROGALL, T. - BLÖCKER, H. - EMDE, M. - BÖTTGER, E.C. 1989. Isolation and direct complete nucleotide determination of entire genes: characterization of a gene coding for $16 \mathrm{~S}$ ribosomal RNA. In Nucleic Acids Research, vol. 17, pp. 7843-7853. 
FERNANDES, E.C.M. - MOTAVALLI, P.P. - CASTILLA, C. - MUKURUMBIRA, L. 1997. Management control of soil organic matter dynamics in tropical land use systems. In Geoderma, vol. 79, pp. 49-67.

GREGORICH, E.G. - CARTER, M.R. - DORNA, J.W. - PANKHURST, C.E. - DWYER, L.M. 1997. Biological attributes of soil quality. In GREGORICH, E.G. - CARTER, M.R. (Ed.) Soil Quality for Crop Production and Ecosystem Health. Amsterdam : Elsevier, pp. 81-114.

HU, S.J. - VAN BRUGGEN, A.H.C. - GRUNWALD, N.J. 1999. Dynamics of bacterial populations in relation to carbon availability in a residue-amended soil. In Applied Soil Ecology, vol. 13, pp. 21-30.

LIU, W.T. - MARSH, T.L. - CHENG, H. - FORNEY, L.J. 1997. Characterization of microbial diversity by determining terminal restriction fragment length polymorphisms of genes encoding $16 \mathrm{~S}$ rRNA. In Applied and Environmental Microbiology, vol. 63, pp. 4516-4522.

LOŽEK, O. 1998. Optimalization of winter wheat nutrition. Slovak Agricultural University in Nitra, 59 pp. ISBN 80-7137-555-1.

LUPWAYI, N.Z. - RICE, W.A. - CLAYTON, G.W. 1998. Soil microbial diversity and community structure under wheat as influenced by tillage and crop rotation. In Soil Biology and Biochemistry, vol. 30, pp. 1733-1741.

MOESENEDER, M.M. - ARRIETA, J.M. - MUYZER, G. - WINTER, C. - HERNDL, G.J. 1999. Optimization of terminal restriction fragment length polymorphism analysis for complex marine bacterioplankton communities and comparison with denaturing gradient gel electrophoresis. In Applied and Environmental Microbiology, vol. 65, pp. 3518-3525.

MUYZER, G. - TESKE, A. - WIRSEN, C.O. 1995. Phylogenetic relationships of Thiomicrospira species and their identification in deep-sea hydrothermal vent samples by denaturing gradient gel electrophoresis of 16S rDNA fragments. In Archives of Microbiology, vol. 164, pp. 165-172.

NORDGARD, L. - TRAAVIK, T. - NIELSEN, K.M. 2005. Nucleic acid isolation from ecological samples - vertebrate gut flora. In Methods in Enzymology, vol. 395 , pp. $38-48$.
PEACOCK, A.D. - MULLEN, M.D. - RINGELBERG, D.B. - TYLER, D.D. - HEDRICK, D.B. - GALE, P.M. - WHITE, D.C. 2001. Soil microbial community responses to dairy manure or ammonium nitrate applications. In Soil Biology and Biochemistry, vol. 33, pp. 1011-1019.

PERRIER, X. - JACQUEMOUD-COLLET, J.P. 2006. DARwin software. http://darwin.cirad.fr/

POULSEN, P.H.B. - AL-SOUD, W.A. - BERGMARK, L. - MAGID, J. - HANSEN, L.H. - SØRENSEN, S.J. 2013. Effects of fertilization with urban and agricultural organic wastes in a field trial - Prokaryotic diversity investigated by pyrosequencing. In Soil Biology and Biochemistry, vol. 57, pp. 784-793.

SARATHCHANDRA, S.U. - GHANI, A. - YEATES, G.W. - BURCH, G. - COX, N.R. 2001. Effect of nitrogen and phosphate fertilisers on microbial and nematode diversity in pasture soils. In Soil Biology and Biochemistry, vol. 33, pp. 953-964.

SHYU, C. - SOULE, T. - BENT, S.J. - FOSTER, J.A. - FORNEY, L.J. 2007. MiCA: a webbased tool for the analysis of microbial communities based on terminal-restriction fragment length polymorphisms of $16 \mathrm{~S}$ and $18 \mathrm{~S}$ rRNA genes. In Journal of Microbial Ecology, vol. 53, pp. 562-570.

TORSVIK, V. - GOKSOYR, J. - DAAE, F.L. 1990. High diversity in DNA of soil bacteria. In Applied and Environmental Microbiology, vol. 56, pp. 782-787.

WARD, D.M. - BATESON, M.M. - WELLER, R. RUFF-ROBERTS, A.L. 1992. Ribosomal RNA analysis of microorganism as occur in nature. In Advances in Microbial Ecology, vol. 12, pp. 219-286.

YAO, H. - HE, Z. - WILSON, M.J. - CAMPBELL, C.D. 2000. Microbial biomass and community structure in a sequence of soils with increasing fertility and changing land use. In Microbial Ecology, vol. 40, pp. 223-237.

YU, W.T. - BI, M.L. - XU, Y.G. - ZHOU, H. - MA, Q. - JIANG, C. 2013. Microbial biomass and community composition in a Luvisol soil as influenced by longterm land use and fertilization. In Catena, vol. 107, pp. 89-95

Received: November 18, 2013 